\title{
DNA Methylation patterns of immune response-related genes in inflammatory external root resorption
}

\author{
Daniela Augusta \\ BARBATO-FERREIRA(a) \\ Sara Ferreira dos Santos \\ $\operatorname{cosTA}^{(b)}$ \\ Ricardo Santiago GOMEZ(b) iD \\ Juliana Vilela BASTOS(a) iD \\ (a) Universidade Federal de Minas Gerais - \\ UFMG, School of Dentistry, Department of \\ Restorative Dentistry, Federal University of \\ Minas Gerais, Belo Horizonte, MG, Brazil. \\ (b) Universidade Federal de Minas Gerais - \\ UFMG, School of Dentistry, Department of \\ Oral Surgery and Pathology, Belo Horizonte, \\ MG, Brazil.
}

Declaration of Interests: The authors certify that they have no commercial or associative interest that represents a conflict of interest in connection with the manuscript.

\section{Corresponding Author:}

Daniela Augusta Barbato-Ferreira

E-mail: danibarbatof@gmail.com

ht1ps://doi.org/10.1590/1807-3107bor-2020.vol34.0087

Submitted: December 23, 2019

Accepted for publication: April 28, 2020

Last revision: May 26, 2020

\begin{abstract}
Inflammatory external root resorption (IERR) is a pathological process defined by the progressive loss of dental hard tissue, dentin, and cementum, resulting from the combination of the loss of external root protective apparatus and root canal infection. It has been suggested that healing patterns after tooth replantation may be influenced by the genetic and immunological profiles of the patients. The purpose of the present investigation was to evaluate the DNA methylation patterns of 22 immune response-related genes in extracted human teeth presenting with IERR. Methylation assays were performed on samples of root fragments showing IERR and compared with healthy bone tissue collected during the surgical extraction of impacted teeth. The methylation patterns were quantified using EpiTect Methyl II Signature Human Cytokine Production PCR Array. The results revealed significantly higher hypermethylation of the FOXP3 gene promoter in IERR (65.95\%) than in the bone group $(23.43 \%)$ $(\mathrm{p}<0.001)$. The ELANE gene was also highly methylated in the pooled IERR sample, although the difference was not statistically significant $(\mathrm{p}=0.054)$. Our study suggests that the differential methylation patterns of immune response-related genes, such as FOXP3 and ELANE, may be involved in IERR modulation, and this could be related to the presence of root canal infection. However, further studies are needed to corroborate these findings to determine the functional relevance of these alterations and their role in the pathogenesis of IERR.
\end{abstract}

Keywords: Epigenomics; Methylation; Inflammation; Replantation; Root Resorption.

\section{Introduction}

Inflammatory external root resorption (IERR) is an undesirable, albeit frequent complication in replanted permanent teeth that causes rapid and irreversible damage to the root structure. The onset of IERR in replanted teeth results from damage to the periodontal ligament (PDL) and cementum during tooth displacement out of its socket, or due to unfavorable storage conditions. The denuded root surface allows pre-osteoclasts to attach and become activated, starting the resorption process aiming to heal the damaged area. ${ }^{1,2}$ However, progressive IERR is only sustained if infection originating from the root canal reaches the external root surface in resorbed areas via exposed dentinal tubules. 
Once bacteria and their byproducts arrive at the PDL space, they switch the ongoing healing process to an immune-inflammatory response. ${ }^{3,4}$

The molecular and cellular events involved in IERR are believed to be similar to those occurring in bone resorption, which are also modulated by soluble factors of the immune response. Interindividual variability of the immune response, and therefore susceptibility to diseases, is regulated by gene expression profiling, ${ }^{5,6}$ which in turn, may be strongly influenced by epigenetic mechanisms. Epigenetics is probably the most significant interface between genetic and environmental factors that gives rise to the phenotype. ${ }^{7}$ It consists of changes in gene expression that are not coded in the DNA sequence itself, but can alter the ability of transcription factors to reach and bind their target DNA, modifying cell behavior by controlling gene expression patterns during the cell cycle, development, or differentiation. ${ }^{8}$ DNA methylation is one of the best-studied and critically important epigenomic modifications. ${ }^{9}$ It is a covalent modification that occurs by the addition of a methyl $\left(\mathrm{CH}_{3}\right)$ group at the $5^{\prime}$ cytosine in the sequence context of cytosine-phosphate-guanine ( $\mathrm{CpG}$ ) dinucleotides . The addition of a methyl group at $\mathrm{CpG}$ islands, which are mostly located in the promoter regions of genes, results in stable silencing of gene expression. ${ }^{10}$ In some circumstances, bacterial challenge and inflammation can induce changes in epigenetic patterns and, consequently, gene expression. Current research has demonstrated the involvement of specific DNA methylation in the pathogenesis of a variety of different oral inflammatory diseases such as periodontitis, ${ }^{7,11}$ and periapical lesions due to pulpal infection. $12,13,14,15$ Such results make it reasonable to assume that these mechanisms may also affect IERR activity. In addition, it has been suggested that the genetic and immunological profiles of patients influence healing patterns after tooth replantation, regardless of the management of the avulsed tooth. ${ }^{16}$

Therefore, the present study aimed to identify methylation patterns in the immune-related genes of patients with IERR. We hypothesize that the epigenetic status of immune response-related genes may harbor different putative methylation sites, which can contribute to the dynamics of IERR development.

\section{Methodology}

\section{Subjects and sample collection}

This study was approved by the Committee on Ethics in Research of the Federal University of Minas Gerais, FUMG (CAAE 11883119.9.0000.5149). All participants gave their written consent to participate.

The case group consisted of 9 replanted permanent teeth referred for extraction (Table 1), presenting radiographic signs of IERR according to Andreasen's criteria $^{17}$ : bowl-shaped radiolucencies at both the root surface and the adjacent bone. Standardized periapical radiographies performed at the visit of extraction, according to previously described criteria ${ }^{18}$ were examined independently by two investigators (DABF and JVB). The control group consisted of 6 samples of healthy bone from patients who required extraction of their third molars. Samples of root fragments presenting with IERR and healthy bone tissue were obtained during the surgical procedure, and were immediately stored at $-80^{\circ} \mathrm{C}$ for later DNA extraction. Patients with systemic conditions requiring the use of bone metabolism modifiers and patients with periodontal disease or radiographic evidence of periodontal bone loss were excluded.

\section{DNA methylation analysis}

Samples of teeth and bone fragments were ground in a tube containing $2.3-\mathrm{mm}$ chrome-steel beads (Biospec, cat. $n^{\circ}$. 11079123c) using a shaker equivalent to a MiniBeadbeater. Genomic DNA (gDNA) was isolated using the DNeasy Blood and Tissue Kit (Qiagen Inc.,

Table 1. Clinical data of subjects presenting with radiographic signs of IERR.

\begin{tabular}{lcccc}
\hline Case & $\begin{array}{c}\text { Tooth } \\
\text { type }\end{array}$ & Gender & $\begin{array}{c}\text { Age at trauma } \\
\text { (years) }\end{array}$ & $\begin{array}{c}\text { Age at extraction } \\
\text { (years) }\end{array}$ \\
\hline 1 & 41 & Male & 6.6 & 7.5 \\
2 & 21 & Male & 7 & 8 \\
3 & 31 & Male & 12.7 & 14.6 \\
4 & 41 & Male & 12.7 & 14.6 \\
5 & 41 & Male & 13.4 & 17.4 \\
6 & 11 & Female & 7 & 9.2 \\
7 & 21 & Female & 7 & 9.2 \\
8 & 11 & Female & 12 & 22 \\
9 & 21 & Female & 12 & 22 \\
\hline
\end{tabular}


Valencia, USA) according to the manufacturer's protocol. The DNA concentration and purity were measured by spectrophotometry using a NanoDropTM 2000 (Thermo Fisher Scientific, Waltham, USA).

The resultant gDNA extracts were obtained to form the case and control groups. All patients contributed the same amount of DNA to the pools. After preparation of the pools, the samples were digested for DNA methylation analysis using the EpiTectMethyl DNA Restriction Kit (Qiagen, Inc., Valencia, USA). The method is based on detection of quantitative DNA after cleavage using four enzyme reactions (without enzymes, methylation-sensitive restriction enzyme, methylation-dependent restriction enzyme, and both enzymes). The methylation-sensitive restriction enzyme and the methylation-dependent restriction enzyme digest unmethylated and methylated DNA, respectively. In accordance with the manufacturer's protocol, $1 \mu \mathrm{g}$ of each pool was used for each digestion reaction.

After the enzymatic digestion phase, analysis of the methylation status of 22 immune response-related genes was performed using EpiTect Methyl II Signature Human Cytokine Production PCR Array (SABiosciences, Qiagen, Valencia, USA) no.335212 EAHS-541ZE). For this analysis, SYBR Green qPCR Master Mix was added to a 96-well PCR array plate containing the 22 primers of promoter genes (Table 2). Real-time PCR was performed using the StepOne Plus Real-Time PCR System (Thermo Fisher Scientific, DE, USA), programed according to the manufacturer's instructions, following established cycling conditions (Table3). Each array includes specific control assays to monitor the cutting efficiencies of methylation-sensitive and methylation-dependent enzymes and to ensure reliable results.
Data were assessed using deltaCt-values. Relative percentages of unmethylated and methylated fractions of input DNA were obtained for each gene in both groups. Data representing DNA methylation levels were analyzed using the EpiTect Methyl II DNA PCR 96-Well Data Analysis spreadsheet, available on the manufacturer's website (Life Technologies, Carlsbad, USA).

The database and statistical analyses were performed using R software (version 3.5.3, Vienna, Austria, 2018). Frequency tables of categorical variables and descriptive statistics were used to describe the profiles of the studied groups. Chi-squared test was used to compare proportions of unmethylated and methylated fractions of input DNA for each gene in both groups. The level of significance was set at $\mathrm{p}<0.05$.

\section{Results}

The methylation levels of the promoter regions of the 22 immune response-related genes in the IERR group and in the control group are presented in Figure. The results of the methylation patterns of the pooled

Table 3. PCR cycling protocol.

\begin{tabular}{|c|c|c|}
\hline Temperature & Time & Number of cycles \\
\hline $95^{\circ} \mathrm{C}$ & $10 \min ^{*}$ & 1 cycle \\
\hline $99^{\circ} \mathrm{C}$ & $30 \mathrm{~s}$ & \multirow{2}{*}{3 cycles } \\
\hline $72^{\circ} \mathrm{C}$ & $1 \mathrm{~min}$ & \\
\hline $97^{\circ} \mathrm{C}$ & $15 \mathrm{~s}$ & \multirow{2}{*}{40 cycles } \\
\hline $72^{\circ} \mathrm{C}$ & $1 \min ^{* *}$ & \\
\hline $\begin{array}{l}\text { According to instrument } \\
\text { recommendations }^{* * *}\end{array}$ & \multicolumn{2}{|c|}{ Melting curve segment } \\
\hline $\begin{array}{l}\text { *Hot-start to activate DNA } \\
\text { Green fluorescence from } \\
\text { each cycle; }{ }^{* *} \text { The tempe } \\
\text { curve are standard for the }\end{array}$ & $\begin{array}{l}\text { lerase; } \\
\text { ell during } \\
\text { time and } \\
\text { al cycler }\end{array}$ & $\begin{array}{l}\text { and record SYBR } \\
\text { nnealing step of } \\
\text { of the melting } \\
\text { ne Plus). }\end{array}$ \\
\hline
\end{tabular}

Table 2. Composition of Epitect Methyl II Signature Human Cytokine Production PCR Array (SABiosciences, Qiagen).

\begin{tabular}{|c|c|}
\hline Group function & Gene symbol \\
\hline T-cell function regulators & BCL10, BCL3, FOXP3, HMOX1, IL12 A, MALT1, MAP3K7, SOD1, STAT5A, TRAF2, TRAF6 \\
\hline B-cell function regulators & BCL10, BCL3, INHA, INHBA, STAT5A \\
\hline Transcriptional regulators & BCL10, BCL3, FOXP3, GATA3, IRF1, SMAD3, STAT5A \\
\hline Translational regulators & BCL3, IGF2BP2 \\
\hline Environment and intracellular stimuli responses & $\begin{array}{c}\text { BCL10, BCL3, ELA2, FOXP3, GATA3, HMOX1, IL12 A, INHA, INHBA, LTB, MALT1, } \\
\text { MYD88,NOD1, SMAD3, SOD1, STAT5A, TLR2 }\end{array}$ \\
\hline Cytokine production signaling molecules & $\begin{array}{c}\text { BCL10, BCL3, FOXP3, HMOX1, INHA, INHBA, LTB, MALT1, MAP3K7, MYD88, NOD1, } \\
\text { SMAD3,SOD1, STAT5A, TLR2, TRAF2, TRAF6 }\end{array}$ \\
\hline
\end{tabular}


IERR samples revealed the highest levels of DNA methylation for FOXP3 and ELANE, in comparison with the levels for the other investigated genes. The FOXP3 promoter region showed $65.95 \%$ methylation level in the IERR pool, while the normal healthy bone pool showed a markedly reduced percentage of DNA methylation (23.43\%) for the same gene
$\left(\mathrm{X}^{2}=36.57, \mathrm{p}<0.001\right)$. A higher level of methylation was also observed for ELANE in the IERR sample pool $(29.07 \%)$ when compared to bone (17.56\%), with the difference being marginally significant $\left(X^{2}=3.75\right.$, $\mathrm{p}=0.054)$. The other evaluated gene promoters showed similar profiles between the case and control groups, presenting low methylation levels (Table 4).

A pool IERR

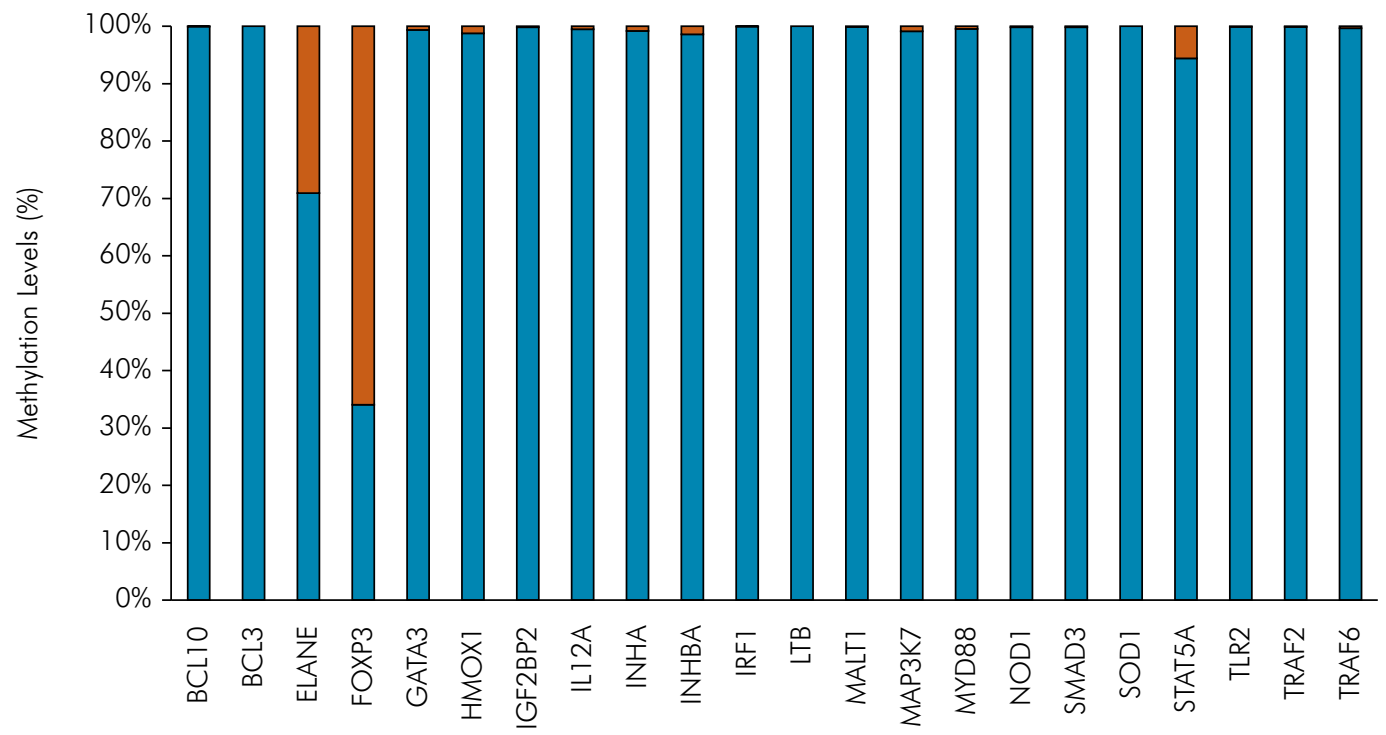

$\square$ Unmethylated $\quad \square$ Methylated

B pool BONE

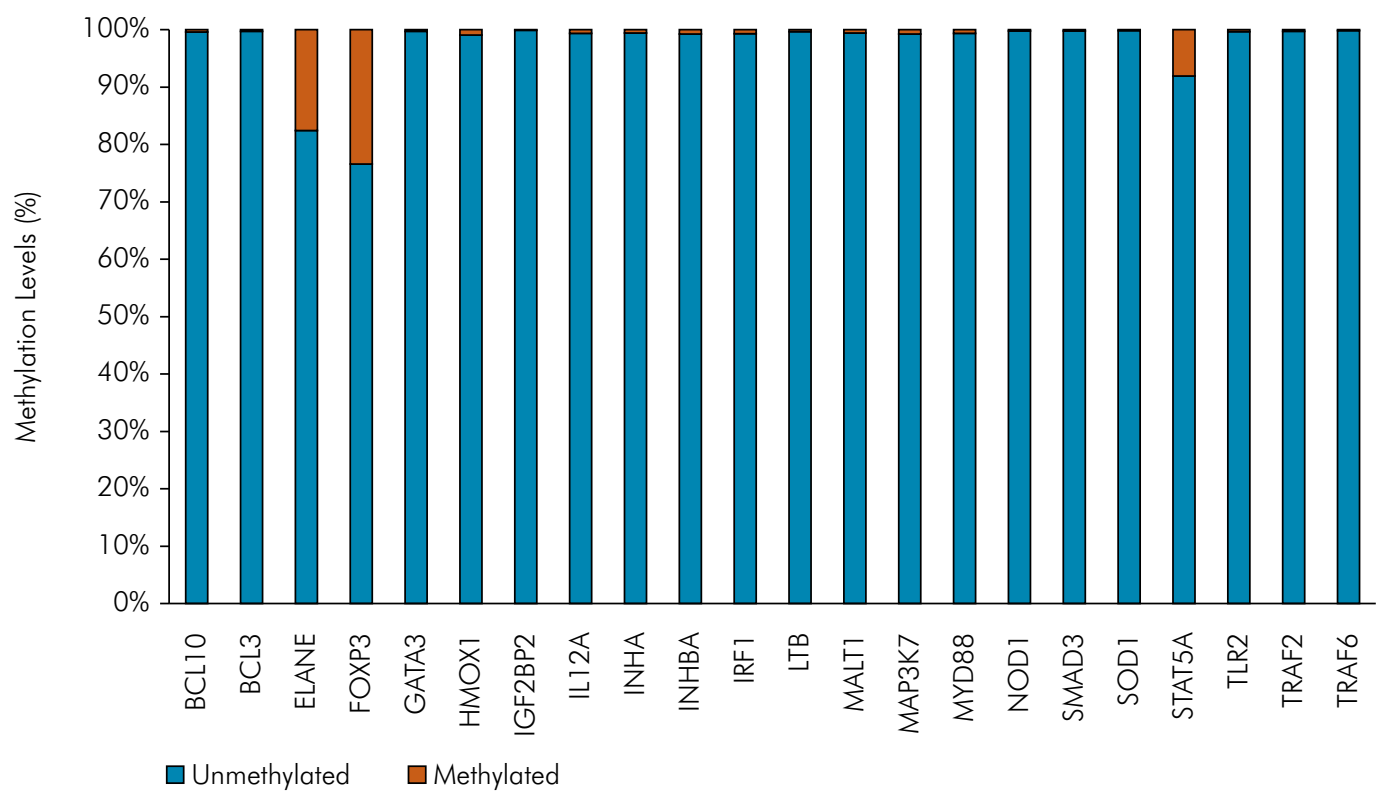

Figure. Relative percentages of unmethylated and methylated fractions for each gene in both groups. A) pool inflammatory external root resorption (IERR); and B) pool bone. FOXP3 $(p<0.00)$ and ELANE $(p=0.054)$ showed the highest levels of DNA methylation in the IERR group when compared to the bone group. 
Table 4. Percentage of unmethylated (UM) and methylated (M) levels in immune response genes in pool IERR and pool bone.

\begin{tabular}{lcccc}
\hline \multirow{2}{*}{ Gene symbol } & \multicolumn{2}{c}{ Pool IERR } & \multicolumn{2}{c}{ Pool bone } \\
\cline { 2 - 5 } & UM (\%) & $M(\%)$ & UM (\%) & $M(\%)$ \\
\hline BCL10 & 99.98 & 0.02 & 99.63 & 0.37 \\
BCL3 & 99.99 & 0.01 & 99.73 & 0.27 \\
ELANE & 70.93 & 29.07 & 82.44 & 17.56 \\
FOXP3 & 34.05 & 65.95 & 76.57 & 23.43 \\
GATA3 & 99.37 & 0.63 & 99.73 & 0.27 \\
HMOX1 & 98.74 & 1.26 & 99.05 & 0.95 \\
IGF2BP2 & 99.81 & 0.19 & 99.92 & 0.08 \\
IL12A & 99.48 & 0.52 & 99.39 & 0.61 \\
INHA & 99.16 & 0.84 & 99.44 & 0.56 \\
INHBA & 98.61 & 1.39 & 99.25 & 0.75 \\
IRF1 & 99.98 & 0.02 & 99.30 & 0.70 \\
LTB & 100.00 & 0.00 & 99.65 & 0.35 \\
MALT1 & 99.89 & 0.11 & 99.43 & 0.57 \\
MAP3K7 & 99.14 & 0.86 & 99.23 & 0.77 \\
MYD88 & 99.55 & 0.45 & 99.35 & 0.65 \\
NOD1 & 99.85 & 0.15 & 99.76 & 0.24 \\
SMAD3 & 99.86 & 0.14 & 99.79 & 0.21 \\
SOD1 & 100.00 & 0.00 & 99.86 & 0.14 \\
STAT5A & 94.41 & 5.59 & 91.92 & 8.08 \\
TLR2 & 99.90 & 0.10 & 99.65 & 0.35 \\
TRAF2 & 99.88 & 0.12 & 99.69 & 0.31 \\
TRAF6 & 99.67 & 0.33 & 99.83 & 0.17 \\
\hline & & & & \\
\hline
\end{tabular}

\section{Discussion}

Tooth replantation represents the treatment of choice for avulsion, although its long-term prognosis shows great variability. Progressive ERR is the most frequent sequel after reimplantation of permanent teeth, with a reported prevalence between $6.4 \%$ and $94.1 \%{ }^{19}$ representing the main cause of untimely tooth loss after replantation with relevant functional, aesthetic, psychological, and economic consequences due to the impossibility of definitive rehabilitation..$^{20,21}$ Nonetheless, the modulation mechanisms of ERR are not completely understood, and the few available clinical studies suggest that the healing process after reimplantation may also be influenced by the host response, regardless of the initial handling and treatment of avulsed teeth. ${ }^{22}$ In this context, the present clinical and molecular study investigated for the first time the methylation status of a selected panel of important inflammatory genes related to immune response in replanted teeth presenting with IERR. These genes comprised B-cell and T-cell function regulators, transcriptional and translational regulators, as well as other genes involved in inflammatory response and immunity. The DNA methylation profile was investigated to compare a pooled sample of root fragments bearing IERR to a pooled sample of normal bone tissue. Epigenetic mechanisms, such as DNA methylation, have been shown to have an impact on the pathogenesis of other inflammatory oral diseases, including periodontitis $\mathrm{s}^{7,11}$ and periapical lesions. ${ }^{12,13,14,15}$

The methylation assays revealed that the FOXP3 promoter showed higher levels of DNA methylation in the IERR group than in the healthy bone group. Additionally, the ELANE gene was also highly methylated in IERR compared to bone, although it did not reach statistical significance. Higher methylation levels of these two promoter genes were also observed in radicular cysts and periapical granulomas ${ }^{13}$ and in reticular oral lichen planus lesions. ${ }^{23}$ ELANE encodes neutrophil elastase protein (NE), a serine proteinase secreted by neutrophils. ELANE has been shown to be essential in the immune defense against pathogen invasion and exerts several effects in tissue remodeling and inflammation, such as processing inflammatory mediators, ${ }^{24}$ disturbing the endothelial cell cytoskeletal architecture to increase vascular permeability, ${ }^{25}$ and facilitating neutrophil transmigration. ${ }^{26}$ FOXP3 is a transcription factor considered necessary and sufficient for the development of regulatory $\mathrm{T}$ cells (Tregs); it is also considered a specific marker for this $\mathrm{T}$ cell subpopulation. ${ }^{27,28,29}$ Treg cells represent a distinct population of $\mathrm{T}$ cells that are induced peripherally by antigen exposure. ${ }^{30}$ The role of Tregs in controlling the immune response via suppression of effector cell function and/or production of immunosuppressive cytokines is well established. ${ }^{28,30}$ In epigenetic studies, a correlation between DNA methylation and gene silencing has long been recognized. It has been suggested that DNA demethylation of the FOXP3 promoter gene in Tregs is a prerequisite for stable 
protein expression and Treg development and for the suppressive regulatory $\mathrm{T}$ cell phenotype. Demethylation allows FOXP3 binding to maintain transcriptional activity at the FOXP3 locus. ${ }^{28,31,32,33}$ On the other hand, the higher level of methylation of the FOXP3 promoter region inhibits transcription factors from binding to their DNA binding sites, since they are correlated with FOXP3 mRNA gene expression downregulation. ${ }^{13}$

Taken together, the present findings, which show a higher methylation status of the FOXP3 and ELANE gene promoter regions in the IERR group as well as in radicular cysts and periapical granulomas, ${ }^{13}$ may reflect the infectious etiopathogenesis shared by such entities. It has been shown that DNA methylation status can change rapidly in response to infection and may have a role in innate immune response. ${ }^{34}$ It has also been shown that microbial pathogens, including bacteria, viruses, and their virulence factors, can further deregulate the epigenetic machinery of the host cell with the intention of circumventing host defense mechanisms, thereby favoring the colonization, growth, or spread of infectious pathogens. ${ }^{35}$ The role of environmental factors, including bacterial infection and tissue inflammation in some oral diseases, have recently been explored and have been shown to be capable of inducing epigenetic changes in pulpal ${ }^{36,37}$ and periodontal tissues..$^{38-39,40}$

Since the FOXP3 promoter gene is encoded on the $\mathrm{X}$ chromosome, most studies choose to use only male donors in order to avoid bias due to the inactivity of the $\mathrm{X}$ chromosome. However, the precise regulation of FOXP3 expression in female donors remains an enigma. ${ }^{29}$ According to a recent study, the methylation patterns of the FOXP3 locus seem to be quite similar in both genders. ${ }^{29}$ Taking this into account, together with the fact that tooth avulsion is a rare traumatic injury in permanent dentition, with an incidence ranging from $0.5 \%$ to $16 \%{ }^{41}$ both genders were included in the same pool. The decision to include female donors was based on the difficulty of obtaining samples of severe IERR in teeth that cannot be saved.

The present study originally provided interesting results regarding the differential methylation patterns in an important gene involved in the immune response in teeth bearing IERR when compared to healthy bone. This suggests that epigenetic mechanisms may participate in IERR modulation. It is noteworthy that there are no previous studies investigating the role of epigenetic regulation in ERR modulation. Clinicians tackling ERR face the most frequent and deleterious sequelae after traumatic dental injuries, with high frequencies reported in clinical studies. Understanding the molecular mechanisms underlying ERR in replanted teeth is the first step in the development of new approaches to manipulate clastic activity, a key point in maintaining traumatized teeth as long as they are needed, even when replanted under unsuitable conditions. Nonetheless, the present data must be interpreted with caution, especially because of the small sample size and the need to assess the functional impact of DNA methylation, by verifying the expression and transcription levels of the mRNA of the FOXP3 and ELANE genes, through validation experiments using individual samples. In addition, multivariate analysis to assess the effect of demographic and clinical factors on IERR activity was not performed. It is well known that the patient's age at the time of trauma ${ }^{18,42}$ and the timing of pulpectomy after replantation ${ }^{18,42}$ may affect IERR activity. Therefore, future studies addressing simultaneous methylation patterns of FOXP3, ELANE, and additional genes as well as other clinical parameters, may also contribute to elucidation of the dynamics of IERR in traumatized teeth.

\section{Conclusion}

The present results indicate the presence of differential methylation patterns of the FOXP3 and ELANE genes in IERR, compared to healthy bone tissue, and suggest that this might be attributed to the presence of root canal infection. This is the first evidence of the possible participation of epigenetic events in the modulation of IERR. However, future studies are needed to corroborate these findings so as to determine the functional relevance of this alteration and its role in the pathogenesis of IERR. 


\section{References}

1. Andreasen JO, Andreasen FM. Root resorption following traumatic dental injuries. Proc Finn Dent Soc. 1992;88 Suppl 1:95-114.

2. Hammarström L, Pierce A, Blomlöf L, Feiglin B, Lindskog S. Tooth avulsion and replantation: a review. Endod Dent Traumatol. 1986 Feb;2(1):1-8. https://doi.org/10.1111/j.1600-9657.1986.tb00117.x

3. Trope M. Avulsion of permanent teeth: theory to practice. Dent Traumatol. 2011 Aug;27(4):281-94. https://doi.org/10.1111/i.1600-9657.2011.01003.x

4. Andreasen JO. Relationship between surface and inflammatory resorption and changes in the pulp after replantation of permanent incisors in monkeys. J Endod. 1981 Jul;7(7):294-301. https://doi.org/10.1016/S0099-2399(81)80095-7

5. Sasaki T. Differentiation and functions of osteoclasts and odontoclasts in mineralized tissue resorption. Microsc Res Tech. 2003 Aug;61(6):483-95. https://doi.org/10.1002/jemt.10370

6. Bastos JV, Silva TA, Colosimo EA, Côrtes MI, Ferreira DA, Goulart EM, et al. Expression of Inflammatory Cytokines and Chemokines in Replanted Permanent Teeth with External Root Resorption. J Endod. 2017 Feb;43(2):203-9. https://doi.org/10.1016/j.joen.2016.10.018

7. Larsson L. Current concepts of epigenetics and its role in periodontitis. Curr Oral Health Rep. 2017;4(4):286-93. https://doi.org/10.1007/s40496-017-0156-9

8. Greenberg MV, Bourc'his D. The diverse roles of DNA methylation in mammalian development and disease. Nat Rev Mol Cell Biol. 2019 Oct;20(10):590-607. https://doi.org/10.1038/s41580-019-0159-6

9. Smith ZD, Meissner A. DNA methylation: roles in mammalian development. Nat Rev Genet. 2013 Mar;14(3):204-20. https://doi.org/10.1038/nrg3354

10. Barros SP, Offenbacher S. Epigenetics: connecting environment and genotype to phenotype and disease. J Dent Res. 2009 May;88(5):400-8. Available from: https://doi.org/10.1177\%2F0022034509335868 https://doi.org/10.1177/0022034509335868

11. Schulz S, Immel UD, Just L, Schaller HG, Gläser C, Reichert S. Epigenetic characteristics in inflammatory candidate genes in aggressive periodontitis. Hum Immunol. 2016 Jan;77(1):71-5. https://doi.org/10.1016/j.humimm.2015.10.007

12. Campos K, Gomes CC, Correia-Silva JF, Farias LC, Fonseca-Silva T, Bernardes VF, et al. Methylation pattern of IFNG in periapical granulomas and radicular cysts. J Endod. 2013 Apr;39(4):493-6. https://doi.org/10.1016/i.joen.2012.12.026

13. Campos K, Franscisconi CF, Okehie V, Souza LC, Trombone AP, Letra A, et al. FOXP3 DNA methylation levels as a potential biomarker in the development of periapical lesions. J Endod. 2015 Feb;41(2):212-8. https://doi.org/10.1016/i.joen.2014.10.003

14. Campos K, Gomes CC, Farias LC, Silva RM, Letra A, Gomez RS. DNA Methylation of MMP9 Is Associated with High Levels of MMP-9 Messenger RNA in Periapical Inflammatory Lesions. J Endod. 2016 Jan;42(1):127-30. https://doi.org/10.1016/i.joen.2015.10.002

15. Wichnieski C, Maheshwari K, Souza LC, Nieves F, Tartari T, Garlet GP, et al. DNA methylation profiles of immune response-related genes in apical periodontitis. Int Endod J. 2019 Jan;52(1):5-12. https://doi.org/10.1111/iej.12966

16. Roskamp L, Westphalen VD, Carneiro E, Fariniuk LF, Silva Neto UX, Westphalen FH. Relationship between extra-alveolar time and atopy in the prognosis of the replantation of avulsed teeth. J Trauma. 2010 Dec;69(6):E79-81. https://doi.org/10.1097/TA.0b013e3181ec112b

17. Andreasen JO, Borum MK, Jacobsen HL, Andreasen FM. Replantation of 400 avulsed permanent incisors. 4. Factors related to periodontal ligament healing. Endod Dent Traumatol. 1995 Apr;11(2):76-89. https://doi.org/10.1111/j.1600-9657.1995.tb00464.x

18. Bastos JV, Côrtes MIS, Goulart EMA, Colosimo EA, Gomez RS, Dutra WO. Age and timing of pulp extirpation as major factors associated with inflammatory root resorption in replanted permanent teeth. J Endod. 2014 Mar;40(3):366-71. https://doi.org/10.1016/i.joen.2013.10.009

19. Souza BD, Dutra KL, Kuntze MM, Bortoluzzi EA, Flores-Mir C, Reyes-Carmona J, et al. Incidence of Root Resorption after the Replantation of Avulsed Teeth: A Meta-analysis. J Endod. 2018 Aug;44(8):1216-27. https://doi.org/10.1016/i.joen.2018.03.002

20. Cortes MI, Marcenes W, Sheiham A. Impact of traumatic injuries to the permanent teeth on the oral healthrelated quality of life in 12-14-year-old children. Community Dent Oral Epidemiol. 2002 Jun;30(3):193-8. https://doi.org/10.1034/i.1600-0528.2002.300305.x

21. Nguyen PM, Kenny DJ, Barrett EJ. Socio-economic burden of permanent incisor replantation on children and parents. Dent Traumatol. 2004 Jun;20(3):123-33. https://doi.org/10.1111/j.1600-4469.2004.00235.x

22. Roskamp L, Silva Neto UX, Carneiro E, Fariniuk LF, Westphalen VP. Influence of Atopy in the Outcome of Avulsed and Replanted Teeth during 5 Years of Follow-up. J Endod. 2017 Jan;43(1):25-8. https://doi.org/10.1016/i.joen.2016.09.020

23. Cruz AF, Resende RG, Lacerda JC, Pereira NB, Melo LA, Diniz MG, et al. DNA methylation patterns of genes related to immune response in the different clinical forms of oral lichen planus. J Oral Pathol Med. 2018 Jan;47(1):91-5. https://doi.org/10.1111/jop.12645

24. Korkmaz B, Horwitz MS, Jenne DE, Gauthier F. Neutrophil elastase, proteinase 3, and cathepsin G as therapeutic targets in human diseases. Pharmacol Rev. 2010 Dec;62(4):726-59. https://doi.org/10.1124/pr.110.002733 
- DNA methylation patterns of immune response-related genes in inflammatory external root resorption

25. Jerke U, Hernandez DP, Beaudette P, Korkmaz B, Dittmar G, Kettritz R. Neutrophil serine proteases exert proteolytic activity on endothelial cells. Kidney Int. 2015 Oct;88(4):764-75. https://doi.org/10.1038/ki.2015.159

26. Wang S, Dangerfield JP, Young RE, Nourshargh S. PECAM-1, $\alpha 6$ integrins and neutrophil elastase cooperate in mediating neutrophil transmigration. J Cell Sci. 2005 May;118(P+ 9):2067-76. https://doi.org/10.1242/jcs.02340

27. Hori S, Nomura T, Sakaguchi S. Control of regulatory T cell development by the transcription factor Foxp3. Science. 2003 Feb;299(5609):1057-61. https://doi.org/10.1126/science.1079490

28. Janson PC, Winerdal ME, Marits P, Thörn M, Ohlsson R, Winqvist O. FOXP3 promoter demethylation reveals the committed Treg population in humans. PLoS One. 2008 Feb;3(2):e1612. https://doi.org/10.1371/journal.pone.0001612

29. Minskaia E, Saraiva BC, Soares MM, Azevedo RI, Ribeiro RM, Kumar SD, et al. Molecular Markers Distinguishing T Cell Subtypes With TSDR Strand-Bias Methylation. Front Immunol. 2018 Nov;9:2540. https://doi.org/10.3389/fimmu.2018.02540

30. Roncarolo MG, Gregori S, Bacchetta R, Battaglia M, Gagliani N. The Biology of T Regulatory Type 1 Cells and Their Therapeutic Application in Immune-Mediated Diseases. Immunity. 2018 Dec;49(6):1004-19. https://doi.org/10.1016/j.immuni.2018.12.001

31. Baron U, Floess S, Wieczorek G, Baumann K, Grützkau A, Dong J, et al. DNA demethylation in the human FOXP3 locus discriminates regulatory T cells from activated FOXP3(+) conventional T cells. Eur J Immunol. 2007 Sep;37(9):2378-89. https://doi.org/10.1002/eji.200737594

32. Polansky JK, Schreiber L, Thelemann C, Ludwig L, Krüger M, Baumgrass R, et al. Methylation matters: binding of Ets-1 to the demethylated Foxp3 gene contributes to the stabilization of Foxp3 expression in regulatory T cells. J Mol Med (Berl). 2010 Oct;88(10):1029-40. https://doi.org/10.1007/s00109-010-0642-1

33. Zheng Y, Josefowicz S, Chaudhry A, Peng XP, Forbush K, Rudensky AY. Role of conserved non-coding DNA elements in the Foxp3 gene in regulatory T-cell fate. Nature. 2010 Feb;463(7282):808-12. https://doi.org/10.1038/nature08750

34. Pacis A, Tailleux L, Morin AM, Lambourne J, Maclsaac JL, Yotova V, et al. Bacterial infection remodels the DNA methylation landscape of human dendritic cells. Genome Res. 2015 Dec;25(12):1801-11. https://doi.org/10.1101/gr.192005.115

35. Niller HH, Banati F, Nagy K, Buzas K, Minarovits J. Update on microbe-induced epigenetic changes: bacterial effectors and viral oncoproteins as epigenetic dysregulators. Future Virol. 2013;8(11):1111-26. https://doi.org/10.2217/fvl.13.97

36. Hui T, Wang C, Chen D, Zheng L, Huang D, Ye L. Epigenetic regulation in dental pulp inflammation. Oral Dis. 2017 Jan;23(1):22-8. https://doi.org/10.1111/odi.12464

37. Mo Z, Li Q, Cai L, Zhan M, Xu Q. The effect of DNA methylation on the miRNA expression pattern in lipopolysaccharide-induced inflammatory responses in human dental pulp cells. Mol Immunol. 2019 Jul;11:11-8. https://doi.org/10.1016/i.molimm.2019.03.012

38. Drury JL, Chung WO. DNA methylation differentially regulates cytokine secretion in gingival epithelia in response to bacterial challenges. Pathog Dis. 2015 Mar;73(2):1-6. https://doi.org/10.1093/femspd/ftu005

39. Holla S, Balaii KN. Epigenetics and miRNA during bacteria-induced host immune responses. Epigenomics. 2015 Oct;7(7):1197-212. https://doi.org/10.2217/epi.15.75

40. Luo Y, Peng X, Duan D, Liu C, Xu X, Zhou X. Epigenetic Regulations in the Pathogenesis of Periodontitis. Curr Stem Cell Res Ther. 2018;13(2):144-50. https://doi.org/10.2174/1574888X12666170718161740

41. Andreasen JO, Andreasen FM, Andersson L. Textbook and Color Atlas of Traumatic Injuries to the Teeth. Wiley; 2007.

42. Hinckfuss SE, Messer LB. An evidence-based assessment of the clinical guidelines for replanted avulsed teeth. Part I: timing of pulp extirpation. Dent Traumatol. 2009 Feb;25(1):32-42. https://doi.org/10.1111/j.1600-9657.2008.00727.x 